Geopolítica(s) Revista de estudios sobre espacio y poder ISSN: 2172-3958

\title{
COVID-19 between Global Human Security and Ramping Authoritarian Nationalisms
}

\author{
Carlos R. S. Milani ${ }^{1}$
}

Recibido: 6 de mayo de 2020 / Aceptado: 10 de mayo de 2020

\begin{abstract}
Like other transnational threats such as climate change, the extinction of biological species, SARS or Ebola, the current COVID-19 confronts the modern utopia of rigid borders between nations and contemporary finance-led neoliberal economic models. Acknowledging the complexity of COVID-19's root causes, this paper builds on the contradictions between science, expertise and policy in the definition of global human security, and sketches five possible future international scenarios. I argue that in the aftermath of the pandemic any sort of future global, regional and state regulation will need to consider transnational threats not only to ensure the security of individuals, but also to guarantee the long-standing durability of the biosphere as a life-supporting system. To uphold this argument, I develop three sections: (i) the nature of the threat; (ii) the geopolitical tensions that COVID-19 heightens; and (iii) possible future scenarios.
\end{abstract}

Keywords: COVID-19 pandemic; global human security; authoritarian nationalism; geopolitical tensions; future scenarios.

\section{[es] COVID-19 entre la seguridad humana global y el aumento de los nacionalismos autoritarios}

Resumen. Al igual que otras amenazas transnacionales como el cambio climático, la extinción de especies biológicas, el SARS o el Ébola, la COVID-19 actual se enfrenta a la utopía moderna de las fronteras rígidas entre las naciones y a los modelos económicos neoliberales contemporáneos liderados por las finanzas. Reconociendo la complejidad de las causas fundamentales de la COVID-19, este artículo se basa en las contradicciones entre la ciencia, la expertise y las políticas en la definición de la seguridad humana global, y esboza cinco posibles escenarios internacionales futuros. Sostengo que, después de la pandemia, cualquier tipo de regulación futura global, regional y al nivel del Estado deberá considerar las amenazas transnacionales no sólo para garantizar la seguridad de las personas, sino también para garantizar la durabilidad de la biosfera como sistema de soporte vital a largo plazo. Para defender este argumento, desarrollo tres secciones: (i) la naturaleza de la amenaza; (ii) las tensiones geopolíticas intensificadas por la COVID-19; y (iii) posibles escenarios futuros.

Palabras clave: pandemia de COVID-19; seguridad humana global; nacionalismo autoritario; tensiones geopolíticas; escenarios futuros.

1 Rio de Janeiro State University, Institute for Social and Political Studies. Senior fellow and grantee with Brazil's CNPq and FAPERJ.

E-mail: crsmilani@iesp.uerj.br 
[pt] COVID-19 entre segurança humana global e incremento do nacionalismo autoritário

Resumo. Como no caso de outras ameaças transnacionais, a exemplo das mudanças climáticas, da extinção de espécies biológicas, da SARS ou do Ebola, a atual pandemia da COVID-19 confronta a moderna utopia de fronteiras rígidas entre nações e os modelos econômicos neoliberais liderados pelos mercados financeiros. Reconhecendo a complexidade das causas da COVID-19, este artigo baseia-se nas contradições entre ciência, expertise e política na definição da segurança humana global, esboçando cinco possíveis cenários internacionais futuros. Eu argumento que, no contexto póspandemia, qualquer tipo de regulamentação global, regional e estatal precisará considerar ameaças transnacionais não apenas para garantir a segurança dos indivíduos, também a sustentabilidade de longo prazo da biosfera como sistema de suporte à vida. Para desenvolver esse argumento, organizo o artigo em três seções: (i) a natureza da ameaça; (ii) as tensões geopolíticas que a COVID-19 intensifica; e (iii) possíveis cenários futuros.

Palavras-chave: pandemia da COVID-19; segurança humana global; nacionalismo autoritário; tensões geopolíticas; cenários futuros.

Sumario. Introduction. 1. The nature of the threat. 2. The geopolitical tensions that COVID-19 heightens. 3. Possible future scenarios. Final remarks: looking for global leadership. References.

Cómo citar: Milani, C. R. S. (2020). COVID-19 between Global Human Security and Ramping Authoritarian Nationalisms. Geopolítica(s). Revista de estudios sobre espacio y poder, 11(Especial), 141-151.

\section{Introduction}

Increased interdependence, breaches between public policies and socioenvironmental needs, continuous bets on the supremacy of the financial and economic domains as the only drivers to development, the unsustainability of a modernity project that insists on the separation between humankind and nature, inter alia, are but a few of the complex root causes at the origin of the current pandemic. Much the same as other transnational environmental and health threats such as climate change, the extinction of biological species, SARS or Ebola, the current COVID-19 confronts the modern utopia of rigid borders between nations from spatial, political and sociological perspectives.

However, the sense of global emergency that COVID-19 has generated is not a crisis that science and some institutions have not foreseen; indeed, nations could have been better equipped to dealing with the pandemic for the simple fact that its upsurge had been anticipated. Not the kind of virus, nor the timing of the outbreak, neither the geographical origin of its eruption... decision makers were not told any of that, but previous reports and warning systems had built scenarios that politicians should have paid attention to. Dany Rodrik cleverly recalls that the World Health Organisation (WHO) revised its global framework to manage epidemic outbreaks based on previous experiences with HIV-AIDS, SARS, MERS, and H1N1 (Rodrik, 2020). It should also be noted that in recent years WHO's Director General has repeatedly informed its member states that the world was not ready for the pandemic that was coming: WHO put out several measures of caution on its 
"Annual report on the global preparedness for health emergencies" published in September 2019. The 2016 World Bank's Pandemic Emergency Financing Facility is yet another example of an early-warning programme available to the international policy-making community prior to the current crisis.

Acknowledging the complexity of COVID-19's root causes and such a circumstantial avowal of policy failure, this paper builds on the contradictions between science, expertise and policy in the definition of global human security. I argue that in the aftermath of the pandemic any sort of future global, regional and state regulation will need to consider transnational threats not only to ensure the security of individuals, but also to guarantee the long-standing durability of the biosphere as a life-supporting system. To uphold this argument, but without any intellectual ambition of exhausting the complexity of the subject, I develop three general ideas, as follows:

(i) the nature of the threat;

(ii) the geopolitical tensions that COVID-19 heightens;

(iii) possible future scenarios.

\section{The nature of the threat}

In very realistic and non-ideological terms the COVID-19 pandemic has shown the genuine contemporary meaning of global human security. No borders, no military power, no economic capacity has been able to hold back its world-wide dissemination. The complexity of the pandemic links local and global scales, natural and social conditions, which means that one must grasp where such scales and conditions intersect in order to be able to analyse COVID-19's spatial, political and sociological consequences.

The new coronavirus has not only reached global diffusion; as a matter of fact, such as SARS, MERS, H1N1 and Ebola, this most recent transnational health threat is also invisible, it comes from everywhere, reaching all individuals irrespective of class, status, nationality, race and gender. It is true, however, that some individuals, groups and nations are more vulnerable than others. Not all people are equally at risk from COVID-19: because people have different levels of exposure, sensitivity and adaptive capacity, some are more at risk from the new coronavirus than others. For instance, in several countries, the elderly and those suffering from heart diseases or diabetes may be victims of social Darwinism. Inequalities, hierarchies and asymmetries matter. That's not new in the world of international relations. COVID-19 has only made them straightforwardly crystal-clear in the way they increase the effects of the disease and the access to its treatment.

The virus alone does not single out individuals, but pre-existing and enduring cultural, social and economic inequalities ensure that the virus discriminates. Because the world is shaped by economic power, nationalism, gender, racism, xenophobia and ecological injustices, the virus does not spread along virgin territories. It empirically validates the reality of preceding and continuous social and economic systems. Who among the world population is in a position to follow the recommendations of the World Health Organization to defend him/herself against the new coronavirus? How will those who do not a home actually be safe? And if 
home is not safe, for instance due to domestic violence, what does safety mean? Who are the health workers and the delivery agents who guarantee not only the safety of those who can stay home, but also the minimal operational standards of the economic system? Who is obliged to work in risky conditions to feed their own families? Who has access to soap or drinking water? Not even traditional media outlets and neoliberal governments have been able to avoid the fact that COVID-19 has emblematically uncovered the crude reality of the social and economic inequalities.

A compelling novelty of this pandemic is the world-wide anthropological experience of fear and death in such a short span of time. COVID-19 has expanded as a security threat that is existential in scope. Individuals from all geographies have felt this health threat in very concrete terms and without excessive intellectual, mediatic or political mediation. The threat has reached individuals in direct, palpable and conspicuous ways. It has touched every one's neighbourhood, families and many households. Different from climate change, where subjectivity, access to information and data interpretation play a central role in the actual construction of anthropogenic climate change as a political problem, COVID-19 is an individual and subjective experience that occurs without too much mediation and too many intervening agents.

Climate change appeals to long-term social representations of sustainable livelihoods on the planet, whereas COVID-19 engages people, health workers, governments and international organisations with a more direct understanding of emergency. As Dale Jamieson recalls, climate change is an abstraction from the weather that people experience - and the weather changes daily or weekly (Jamieson, 2011). Climate change debates occur in a fertile soil for a diversity of interpretations and perspectives. Without a doubt, media outlets and social networks disseminate news about COVID-19 (and fake news), show how scientists research the development of vaccines, health workers exhort people to wear masks, or still how universities monitor statistics and publish them widely. By all means, the lethality of the new coronavirus and its global diffusion have mobilised some media and political powers to attempt measures to cope with the consequences of the crisis, but not its causes.

At the end of the day, however, individuals are left alone facing their destiny in concrete terms with an increased sense of finite existence. This paradoxical experience of COVID-19 associates (sometimes) mandatory isolation measures with global interdependence. Families living in shared spaces or individual homes are asked (or forced) to comply with absolute or relative isolation, whereas the new coronavirus rapidly travels across borders irrespective of the very modern conception of a national territory. Yet does this experience of pain and fear, which is at the same time subjective and collective, generate bonds of solidarity? Does today's fear of death guarantee a more cooperative world order in the future?

\section{The geopolitical tensions that COVID-19 heightens}

There are at least two geopolitical tensions that the current pandemic enhances significantly. First, the tension between its global and transnational dissemination 
and the principle of sovereignty as a locus of political responsibility. Second, a sense of emergency versus a multilateral system that lacks operational skills.

Concerning the first tension, governments have a primary responsibility towards their nationals, even though they pertinently know that not a single country can be safe until all governments control the pandemic. Their main goal is to eradicate COVID-19, but the international lack of union and cooperation, at least at the very beginning of the epidemic, has strengthened the common enemy, moving countries further away from the shared goal of fighting against the virus' dissemination and the disease's transformation into a global pandemic.

Effective responsibility against a security threat that is not produced by an identifiable enemy who intends to attack a particular state and whose impacts are direct, physical and not respectful of national boundaries necessarily implies a global collective action, not only local solutions. This is an old paradox in international relations, analysed by Kenneth Waltz in his Theory of International Politics:

The likelihood that great powers will try to manage the system is greatest when their number reduces to two. With many great powers, the concerns of some of them are regional, not global. With only two, their worries about each other cause their concerns to encompass the globe. For all but the United States and the Soviet Union, problems are local or regional. They are certainly less than global. (Waltz, 1979, p. 198).

Bearing such a paradox in mind, which perfectly applies to military attacks by external adversaries against the state's sovereign territory, it is important to adequately characterize the nature of the security threat in order to determine proper policy responses. Moreover, it is also relevant to ensure that the conceptualization of security is appropriate. In its nature a military attack of an armed force is absolutely different from transnational diseases or unpredictable catastrophic events. These transnational threats also differ in the design and application of appropriate governmental responses to cope with their respective insecurity effects. Thinking of the diversity of security threats should allow decision makers to deal with a broad spectrum of policy responses. The security of the sovereign state, the population security and vital systems security require different modes of intervention from governments both nationally and internationally (Collier \& Lakoff, 2015; Taleb, 2007). As John Agnew recalls in his concept of the "territorial trap", ignoring the reality of global transnational threats would lead decision makers to imagine the world as a series of separate boxes and prompt states to end up making irrational choices (Agnew, 1994).

Moreover, what COVID-19 has exemplarily shown is that local solutions vary across countries and regions. And this variation may have unsound effects on others, both individually and collectively. Contrasting experiences largely owing to more comprehensive testing and the earlier imposition of travel restrictions, or to a timely declaration of a state of emergency and the closing down of non-essential public services may produce different effects within and across countries. The only adoption of local solutions to cope with global threats may produce irrational outcomes. Even countries with past trajectories of welfare policies and less unequal systems of access to health care are confronted with difficulties in dealing with the spread of the new coronavirus. They are not defenceless when they are compared 
to developing countries, but they are still very vulnerable to the COVID-19. In addition, it is true that as far as the COVID-19 is concerned, decision makers must draw on some of the lessons the world is still learning; however, states and multilateral organisations urgently need to devise a more effective approach to global public health that integrates new national, regional, and international binding policies and initiatives.

The second geopolitical tension that I want to point out in this section relates to the sense of emergency that COVID-19 has produced across countries opposed to a multilateral system that unquestionably lacks operational and mandatory capacity. Two examples may illustrate this argument: the UN Security Council and the World Health Organisation.

As Secretary General António Guterres highlighted, the current pandemic is the gravest test since the founding of the UN, posing a significant threat to the maintenance of international peace and security that may also lead to an increase in social unrest and violence (Guterres, 2020). In a clear attempt to engage the Security Council in the global fight against COVID-19, Mr. Guterres emphasized that the pandemic represents at least eight different kinds of potential threats: (i) to further erode trust in public institutions; (ii) to enhance major socioeconomic stressors, particularly in fragile societies, less developed countries and those in transition; (iii) to generate political tensions due to the postponement of elections or referen$\mathrm{da}$, thus opening windows for political opportunism; (iv) to escalate violence in conflict settings where actors may decide to promote further division and turmoil; (v) to revive the threat of terrorism, particularly in the Sahel and in the Great Lakes region; (vi) to increase risks of bioterrorist attacks; (vii) to hinder international, regional and national conflict resolution efforts; and (viii) to trigger or exacerbate human rights challenges related to stigma, discrimination, hate speech, white supremacy, extremisms and growing authoritarian manifestations (Guterres, 2020).

In spite of the Secretary General's appeal, the UN Security Council has been very slow to act, remaining silent due to traditional divisions between the United States, China and Russia until 9 April, when thanks to a diplomatic push by Germany it finally held its first meeting on the COVID-19 pandemic. Since mid-April, Council members have been negotiating a draft resolution led by Tunisia and supported by France. Will the Security Council be able to speak with one strong voice on this crisis? Will it be able to foster coordination and cooperation? Will it be able to defend a more equitable, efficient and timely access to future vaccines developed to fight coronavirus, as requested by the UN General Assembly?

The other multilateral stance that has been in the spotlights for the last months is the World Health Organisation. Created in 1948, WHO is an intergovernmental organisation which now brings together 194 member states. According to its Constitution, besides the surveillance of infectious diseases and the coordination of the international response in the event of an epidemic, its other central missions concern the development of international standards in the field of health, capacitybuilding, research promotion, and policy advice. WHO's main normative role concerns the development of the International Pharmacopoeia and the International Health Regulations. During the current pandemic, WHO has fostered the role of science, the development of public health and the need for preventive measures in the fight against the new coronavirus. 
Nevertheless, its recommendations have been attacked by some governments, like in the case of the US and Brazil. Jair Bolsonaro has personally helped spreading misinformation, disinformation and defamatory messages against his opponents, in an attempt to undermine the severity of COVID-19, discredit measures recommended by the Organisation and increase public distrust of health statistics and data (Ricard \& Medeiros, 2020). Donald Trump has pushed it further and threatened to pull American financial contribution from WHO. He has also accused the UN agency of being "wrong on many things" and of "being very Sino-centric" (Smith, 2020). Such political behaviour and series of accusations from two allied leaders in the Americas aim certainly to leave behind national practices of denial and erratic measures that characterize both administrations vis-a-vis the crisis of the new coronavirus. In Latin America other important leaders, such as Argentina's Alberto Fernández and Peru's Martín Vizcarra, have acted very differently, much more in conformity with WHO's recommendations. Will other state leaders learn from the negative effects such political behaviour has on the population security? Will they agree to revitalize and found new institutional arrangements within a reformed World Health Organization, with a wider mandate and greater enforcement authority? Will a reinforced WHO have the capacity to design and impose safer protocols for preparedness and reaction, compel data sharing, and mobilize resources?

\section{Possible future scenarios}

In this section, I outline in a very simplified fashion five comprehensive and nonexcluding scenarios that international and transnational, state and non-state actors may be confronted with in a post-pandemic context. First, the most obvious one is the escalating rivalry between the USA and China. The global crisis caused by the pandemic is yet another episode to shed light on the erosion of the Western international order, thus heightening and expanding an existing competition between the two superpowers. The pandemic adds to pre-pandemic perceptions of the US as a free rider. Washington no more benefits from the image of a benign superpower that used to guarantee an order based on international institutions and global economic prosperity. It is true, this narrative has structurally and theoretically been highly contested by many scholars since at least the dismantlement of the Bretton Woods system in the seventies; however, the aftermath of Iraq's invasion in 2003 and, most recently, nationalistic decisions taken by Donald Trump's administration in the fields of climate change, international development and access to Chinese masks have totally weakened the benevolent fiction that liberal pundits have normally associated with the role of the US in international affairs. If the nineties could have been analysed as the peak of American international legitimate power, nowadays there is a clear global power repositioning in a chessboard where China plays an increasingly pivotal role in economic, institutional and normative terms.

Second, national health (and food systems) may become high politics in the new post-pandemic international order. Many governments, but also the world-wide population, have realized the relevance of estimates on the national economic and security implications of health threats. Health is directly associated with the population security, a central dimension in global human security policies. With the 
advancement of the new coronavirus, everyone has become aware that the production of medicines, individual security equipment, masks and many other medical or hospital materials is concentrated in a few countries, including China. It is true that the USA is one of the key producing countries of such equipment and materials, but the pandemic has shown that it is far from being self-sufficient. Not only Washington depends on other countries, but it must also rely on China, its main geoeconomic and geopolitical rival, for medicine, equipment and input for finished products.

According to the World Trade Organization (WTO), COVID-19 relevant medical products are categorized into four main groups: (i) medicines (pharmaceuticals); (ii) medical supplies (alcohol, syringes, gauze, reagents, etc.); (iii) medical equipment and technology; (iv) personal protective products (sanitizer, face masks, protective spectacles). With regard to items for treatment of COVID-19, Germany, the USA and Switzerland supply $35 \%$ of medical products; China, Germany and the US export $40 \%$ of personal protective products. China supplied $25 \%$ world exports of face masks in 2019, and together with Germany and the US, the three contribute to almost half of the world face mask supply (WTO, 2020).

Table 1. Top 10 importers of medical goods, 2019

\begin{tabular}{|c|c|c|c|c|c|c|c|}
\hline \multirow[b]{2}{*}{ Country } & \multicolumn{2}{|c|}{ Total imports } & \multirow[b]{2}{*}{$\begin{array}{c}\text { Share of } \\
\text { world } \\
\text { medical } \\
\text { imports } \\
(\%)\end{array}$} & \multicolumn{4}{|c|}{ Share of total medical imports ( $\%$ ) } \\
\hline & $\begin{array}{c}\text { Value } \\
\text { (\$ billion) }\end{array}$ & $\begin{array}{l}\text { Share of } \\
\text { imports } \\
\text { of all } \\
\text { products } \\
(\%)\end{array}$ & & $\begin{array}{c}\text { Medical } \\
\text { equipment }\end{array}$ & $\begin{array}{l}\text { Medical } \\
\text { supplies }\end{array}$ & Medicines & $\begin{array}{l}\text { Personal } \\
\text { protective } \\
\text { products }\end{array}$ \\
\hline World & $1,011.3$ & 6 & 100 & 14 & 17 & 56 & 13 \\
\hline 1. United States & 193.1 & 8 & 19 & 16 & 16 & 59 & 10 \\
\hline 2. Germany & 86.7 & 7 & 9 & 12 & 18 & 57 & 13 \\
\hline 3. China & 65.0 & 3 & 6 & 23 & 15 & 46 & 16 \\
\hline 4. Belgium & 56.6 & 13 & 6 & 8 & 12 & 75 & 5 \\
\hline 5. Netherlands & 52.7 & 8 & 5 & 16 & 20 & 55 & 8 \\
\hline 6. Japan & 44.8 & 6 & 4 & 16 & 16 & 56 & 13 \\
\hline 7. United Kingdom & 41.1 & 6 & 4 & 11 & 15 & 62 & 12 \\
\hline 8. France & 40.5 & 6 & 4 & 12 & 20 & 53 & 15 \\
\hline 9. Italy & 37.1 & 8 & 4 & 9 & 15 & 66 & 9 \\
\hline 10 Switzerland & 36.9 & 13 & 4 & 6 & 9 & 80 & 5 \\
\hline
\end{tabular}

Source: WTO, Trade in Medical Goods in the Context of Tackling COVID-19 (p. 3).

As shown in Table 1, the USA accounted for $19 \%$ of total world imports of medical goods in 2019. Germany had a share of $9 \%$, followed by China and Belgium $(6 \%)$. Breathing apparatus, including respirators and ventilators, are supplied by a small number of Members notably, Singapore which has $18 \%$ market share, followed by the US with 16\%, Netherlands $10 \%$ and China 10\% (WTO, 2020). Countries may increase their national production for the sake of national and global sanitary emergency, but production timetables do not necessarily correspond to urgent needs. China, for instance, is producing approximately 116 million masks a day, twelve times more than before COVID-19 (Bradsher \& Swanson, 2020). Even so, it cannot meet the simultaneous demand from so many countries. Analysing such data allows us to understand why the pandemic has produced strategic vulnerability risks. Given the seriousness of the pandemic, it has even been treated as a question of war: Donald Trump, for instance, adopted the Defense Production Act (law dates back to the Korean War in the 1950s) to compel American industries to produce hospital equipment and supplies.

Third, ramping authoritarian nationalisms get strengthened North and South portraying additional cases of violence against scientific institutions and public 
health authorities. Nationalisms with anti-science and anti-intellectual visions embody new waves of intensified denial campaigns, manufacturing uncertainty and also undermining security recommendations stemming from the World Health Organisation. Bloggers, self-designated experts, astroturf groups, ultraconservative politicians and media outlets who evolve around authoritarian leaderships tend to paradoxically share a strong commitment to free market and a consistent disdain for governmental or intergovernmental regulatory efforts. One of the most praised metaphors used by nationalist leaders is "we are at war" and fighting an enemy may justify the democratic State's going beyond the normal game of its political nature. The state of fear that has evidently spread across countries may offer the ideal pretext for authoritarianism.

As part and parcel of such movements, nationalistic leaders tend to defend selfcentred and sometimes eugenic reactions to the pandemic: at war will survive only those who are healthier and younger. As the Hungarian, the Serbian, the Indian and the Brazilian cases illustrate, the pandemic context may give authoritarian leaders the "perfect excuses" to try moving much beyond rule of law, freedom of expression and respect for human diversity. Because the current crisis is causing greater fear, some may in return have a desire to seek the comfort of a powerful leader, thereby putting democracies at risk, particularly in local contexts where political institutions are more fragile. In a vicious circle, fearful populations may accept the limitation of freedom imposed by authoritarian governments for the sake of reducing risks and insecurity induced or enhanced by the same governments or leaders.

However - and this leads us to the fourth scenario - confined people around the world also watch on TV and computer screens how absurd it is for governments to deny what medical doctors, epidemiology experts and collective health scientists publicly proclaim as best practices against the dissemination of the new coronavirus. People may also find it absurd to see governments around the world engage in selfish competitions one against the other for medical material, security equipment and ventilators. If this does not necessarily and always activate bonds of international or transnational solidarity, in some settings it may perhaps reactivate the desire for domestic social welfare policies. In the current pandemic context, many governments were obliged to abandon austerity fiscal and financial policies to suddenly implement protective measures, thus essentially responding to the needs of people at risk. In this scenario, societies may wake up and increase waves of resistance against neoliberal economics and geopolitics. The pandemic has shown the clear linkages between economic austerity policies embraced by financial agencies, governments' decisions to reduce social policy budgets and the increase of risks related to global human security. As a social model, neoliberal capitalism will have no future if societies finally understand why governments are in place. Neoliberalism combined with the dominance of financial capital is socially and politically discredited in light of the tragedy that has so far killed more than 250,000 individuals and put the lives of other millions at risk. Before the pandemic, media outlets used to present the omnipresent market as the central economic development actor, whereas since COVID-19's upsurge, scientists and researchers, health workers, State-led public funding and emergency measures have come back to the forefront of policy solutions as if by magic. Indeed, neoliberalism has become a liability for the future of global human security. Its dire consequences are more evident than ever during this pandemic. 
Finally, a fifth possible scenario (perhaps more hopeful than possible...) is an increased awareness among government leaders, civil society organisations, the private sector and individuals of the much-needed use of the precautionary principle in policy making but also in daily economic, technological and social decisions. From local to global scales, the new coronavirus, like climate change and other environmental threats, connects small markets to economic transnational flows. Its causes and effects are not fully known. Its prevention through a vaccine is not yet available. In such a context, the precautionary principle stresses caution, suspending some decisions, calling time for thinking and research before developing innovations or adopting policies that may prove dangerous. The principle should apply when there is potential harm from taking a decision and at the same time when convincing evidence is not yet available.

Based on the precautionary principle, the pandemic opens the way for the necessary capitalism reforms in order to face climate change challenges. However, will incentive packages for post-pandemic economic recovery embrace the importance of aligning efforts to revitalize national economies with actions to mitigate and adapt to climate change? Will politicians prioritize climate change as a security threat more seriously than ever before? The current pandemic plays out much more quickly than the effects of human-induced climate change. However, the principle is the same: if you do not act before you can see the actual impact of the new coronavirus, it may be too late to stop its dissemination. Individuals, governments and international organisations must anticipate scenarios and act based on the precautionary principle so as to prevent the negative effects of the disease.

\section{Final remarks: looking for global leadership}

Focusing on health threats as a global human security issue may give rise to new metrics for screening and monitoring national and international public policies. Policies that increase global human insecurity by reducing people's access to water, sanitation, health services and basic needs should be negatively assessed. Policies that undermine the population security and the security of vital systems of the biosphere should also be unfavourably valued. Global human security as a new conception of security going beyond Realism in International Relations and Neoliberal Economics should help humankind engage with post-pandemic strategies and policies as if the intervention of the new coronavirus could serve as a general rehearsal for the next crisis.

I hypothesize, like many, that the health crisis is preparing, inducing, encouraging people to adapt and get ready for future transnational threats, including climate change. As I said in this article, there are differences between security threats generated by a health pandemic and by climate change. Moreover, it is still necessary to test this hypothesis against empirical obstacles, such as the lack of a clear political leadership, the crash of global oil prices and its effects, scientific denialisms, the essential role of transnational finance in neoliberal capitalism and re-emerging authoritarian nationalisms which tend to undermine the importance of multilateral organisations. 


\section{References}

Agnew, J. (1994). The territorial trap: the geographical assumptions of international relations theory. Review of International Political Economy, 1(1), 53-80.

Bradsher, K., \& Swanson, A. (2020). The US needs China's masks, as acrimony grows. The New York Times, 23 March. Retrieved from https://www.nytimes.com/2020/03/23/business/coronavirus-china-masks.html

Collier, S. J., \& Lakoff, A. (2015). Vital Systems Security: Reflexive Biopolitics and the Government of Emergency. Theory, Culture \& Society, 15(32), 19-51.

Guterres, A. (2020). World Faces Gravest Test since Founding of the United Nations. United Nations. Retrieved from https://www.un.org/press/en/2020/sgsm20041.doc.htm

Jamieson, D. (2011). The Nature of the Problem. In J. S. Dryzek, R. B. Norgaard and D. Schlosberg (Eds.), The Oxford Handbook of Climate Change and Society (pp.38-54). Oxford: Oxford University Press.

Ricard, J., \& Medeiros, J. (2020). Using misinformation as a political weapon: COVID-19 and Bolsonaro in Brazil. The Harvard Kennedy School Misinformation Review, 1(2), 16.

Rodrik, D. (2020). Will Covid-19 remake the world? Project Syndicate, 6 April. Retrieved from https://www.project-syndicate.org/commentary/will-covid19-remake-the-worldby-dani-rodrik-2020-04

Smith, D. (2020). Trump threatens to hold WHO funding, then backtracks, amid search for scapegoat. The Guardian, 7 April. Retrieved from https://www.theguardian.com/usnews/2020/apr/07/trump-coronavirus-who-funding-deaths-briefing

Taleb, N. N. (2007). The Black Swan: The Impact of the Highly Improbable. New York: Random House.

The World Trade Organisation. (2020). Trade in Medical Goods in the Context of Tackling Covid-19. WTO Information note, 3 April. Retrieved from https://www.wto.org/english/news_e/news20_e/rese_03apr20_e.pdf

Waltz, K. N. (1979). Theory of International Politics. Reading, $\bar{M} A$ : Addison-Wesley Publishing. 